\title{
THE “URBAN GEOLOGY” PROJECT OF IGME: THE CASE STUDY OF NAFPLIO, ARGOLIS PREFECTURE, GREECE
}

\author{
Tsombos P. I. ${ }^{1}$ and Zervakou A. D. ${ }^{1}$ \\ ${ }^{1}$ Institute of Geology and Mineral Exploration (I.G.M.E.), Olympic Village, 3rd Entrance, 13677 Acharnae, \\ Athens,Greece,ptsombos@igme.gr,zervakou@igme.gr
}

\begin{abstract}
The Institute of Geology and Mineral Exploration of Greece (I.G.M.E.), in the framework of CSF 2000 - 2006 (Community Support Framework 2000-2006), implemented the pilot project "Collection, Codification and Documentation of geothematic information for urban and suburban areas in Greece - pilot applications". Geological, geochemical, geophysical, geotechnical, hydrogeological and other geothematic data concerning the urban and surrounding areas of Drama (North Greece), Nafplio \& Sparti (Peloponnese) and Thrakomakedones (Attica) were collected. Drillings, geological and neotectonic mapping and other "in situ" measurements and field work took place. All initial and derived analogical and digital data were compiled and processed in specially designed geo-databases in GIS Environment. The final results are presented in geothematic maps and other digital products (DEMs, 2D - 3D surfaces, geodatabases). Such data constitute the essential knowledge base for land use planning and environmental protection in specific urban areas. Through this pilot project, new scientific approaches, methodologies and standards were developed and improved in order to apply to other future projects concerning the major cities of the whole country.
\end{abstract}

Key words: Urban Geology, geothematic mapping, GIS, pilot areas, Nafplio.

\section{Introduction}

The Institute of Geology and Mineral Exploration of Greece (I.G.M.E), in the framework of CSF 2000 - 2006 (Community Support Framework 2000-2006, Operational Program Competitiveness, Priority axis 7: Energy and Sustainable Development, Measure 7.3: Exploitation of natural recourses and support in meeting environmental commitments, Action 7.3.1) implemented the project titled "Collection, codification and documentation of geothematic information for urban and suburban areas in Greece - pilot applications".

Through the implementation of this project, existing geothematic information concerning geological, hydrogeological, geotechnical, geochemical and geophysical reports for urban and suburban areas over the whole country was compiled into a database. Data recording and management was achieved through the use of GIS technology.

Additionally, the geoscientific information was enriched with data derived from "in situ" survey at four pilot areas of different geological structure (Nafplio, Drama, Sparti and Thrakomakedones). All geoinformation from geological mapping, geotechnical - geochemical - geophysical research and measurements was stored and processed in specially designed geodatabases in GIS environment. 
Through the compilation of geological data, this Urban Geology project aimed to the understanding of the surface and subsurface geology of the specific area. Thus, the knowledge of the geological conditions will constitute an essential base for the identification and evaluation of geohazards relating to natural processes and human activities at the wider study area.

All derivative project results and digital data (geodatabases, thematic maps, 3D models - surfaces) are available to:

-State's services in charge of the protection and enhancement of natural and human made environment

-State authorities and engineers whose activities concern infrastructure development and big public works

-Authorities dealing with the confrontation of major natural disasters

-Archaeological services

This project should be the starting point for future relative studies concerning any big city of the whole country or individually where it is required.

\section{Historical overview of Urban Geology studies}

Only a hundred years ago, there were no cities on earth with a population of 5 million residents. Nowadays, the urban enlargement and overpopulation of the western areas is an increasing tendency. It is estimated that there are over 60 such cities. Half of the world's population lives in urbanized areas which cover only $0.7 \%$ of the total earth surface (according to IWGUG).

The aggregation of population leads to the concentration of human activities and economic wealth, over consumption of natural resources and urban growth without planning and sustainable management. As a result, urban societies are exposed to various dangers and threats with economic, social, ecological - environmental impacts on the urban surroundings.

Problems associated with urban development are addressed by the International Working Group on Urban Geology. These problems are related with geological and hydrological conditions of urban areas and those of their surroundings, e.g. flooding, land subsidence, groundwater pollution, soil contamination, earthquakes, volcanic eruptions, coastal and river erosion, landslides, sinkholes, soft and expansive soils causing foundation instability, etc.

For all these reasons, no sustainable urban planning can be done without geological information support. The field of Urban Geology is working towards inducing decision makers and planers to take into account all geological factors in order to predict and minimize natural hazard, protect and harmonize natural environment.

Urban Geology studies rely on diverse branches of earth sciences such as hydrology, engineering geology, geochemistry, stratigraphy and geomorphology in order to build a three-dimensional model of the character of the land and to explain the geological processes involved in the dynamic equilibrium of the local environment (Giroux and Bélanger, 2003).

In the past, traditional approaches on Urban Geology were mostly focused on the mechanical behavior of different geological materials under the cities and the identification of infrastructures stability (roads, buildings). Today the environmental - geological researches, focused on urban areas, cover a wide variety of queries, such as potable water supply, waste disposal, soil vulnerability etc.

The necessity for Urban Geology in the United States was born as settlement spread into the haz- 
ard-prone lands of the West. Prior to about 1950, few maps presented engineering geology data and, if they did, it was intended for the use of engineers, not planners (Rau, 2005).

The need for maps of Urban Geology was recognized publicly in Canada at the turn of the century and probably well before by individual practitioners. In a paper presented to the Royal Society of Canada in 1900, Dr. H. M. Ami said "The larger cities of our Dominion, as well as those of other countries, are the centers of work and research in the pathways of science and commerce. . What the drill has to penetrate in any one of our larger centers of activity in Canada is a question not only of interest but also of economic value." He proceeded to give summary accounts of the Urban Geology of Saint John, Montreal, Ottawa, Quebec, and Toronto, and this, almost seventy years ago (Legget, 1969).

The concern over the urban development and its environmental impacts promotes the collaboration and close interaction between geoscientists, environmental scientists, engineers, planers, decision makers. This multidisciplinary approach has lead to the increase of relevant scientific publications such as "Environmental Geology" (Springer), "Environmental \& Engineering Geosciences" (Geological Society of America and Engineering Geologists), "Environmental Modeling and Assessment" (Baltzer Science Publishers), "Journal of Environmental Planning and Management" (Carfax Publishing) and "Environment and Urbanization" (International Institute for Environment and Development).

In 1991, International Working Group on Urban Geology (IWGUG) was established to provide an international platform in which geoscientists and non-geoscientists can discuss issues of mutual interest concerning urban development. Both the International Association of Engineering Geology (IAEG) and the International Association of Hydrogeologists (IAH) supported this initiative to form a Working Group and joined as founding members.

\section{Case study: Pilot area of Nafplio, Argolis prefecture, Peloponnese, Greece}

\subsection{Work tasks outline}

The third subproject of the Urban Geology Project of I.G.M.E. titled "Integrated geological, geotechnical, hydrogeological, geochemical, geophysical and marine studies of urban and suburban area of Nafplio, Argolis Prefecture" realized at the broader area of Nafplio. The total study area covered a surface of $50 \mathrm{Km}^{2}$ (Fig.1).

The project focused on the collection of field work data and other geological information generated from previous studies of the urban and surrounding area of the city. Fieldwork comprised (Zervakou A. et al., 2007):

- Geological mapping at 1:5.000 scale for the identification and evaluation of geological settings in the study area.

- Neotectonic mapping at 1:5.000 scale for the identification and evaluation of active faults in the study area.

- Geotechnical mapping at 1:5.000 scale for the identification and evaluation of physical, mechanical and geotechnical properties of geological formations in the study area.

- Water and soil field sampling for geochemical analyses.

- Radon measurements.

- Surface geophysical measurements.

- Deep geophysical measurements. 


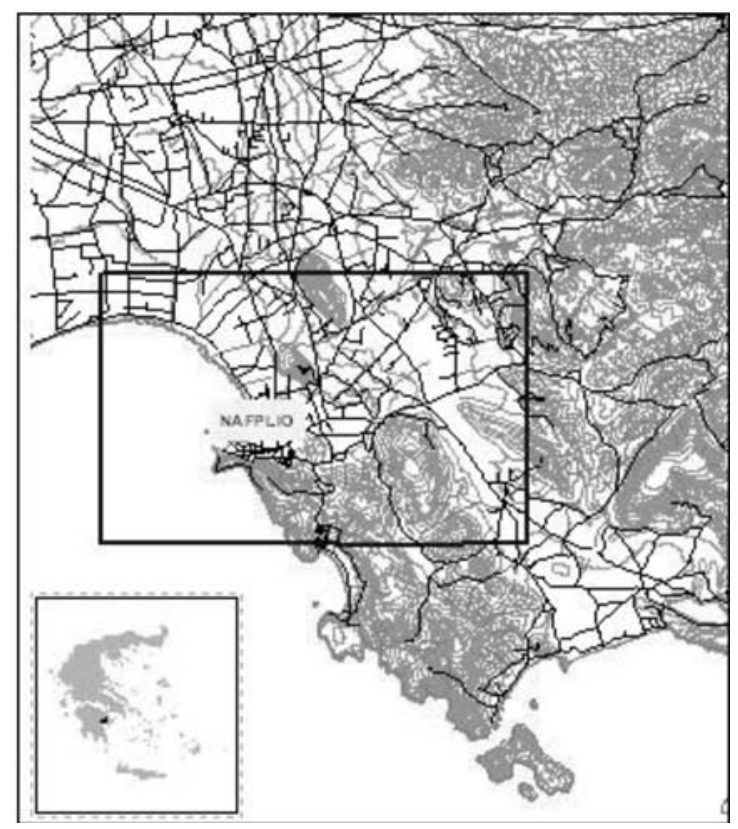

Fig. 1: Reference map of Nafplio's broader area. The black line outlines the study area (Zervakou A. et al, 2007).

- Marine geological survey

- Fieldwork survey for the verification of remote sensing data interpretation

- Geoarchaelogical survey

After the field survey and data acquisition, the following work tasks were implemented (Zervakou A. et al., 2007):

- Soil and water laboratory tests and geochemical analyses.

- Soilmechanics, rockmechanics laboratory tests for the determination of physical and mechanical properties of the penetrated formations.

- Test shallow drillings ("in situ" SPT and permeability tests).

- Data elaboration.

- Data evaluation.

- Data input, management and analysis in GIS environment.

- Digital thematic maps compilation in GIS environment.

- Technical reports, publications.

\subsection{Accomplished tasks}

During the project the following work tasks were carried out:

1. Geological mapping at 1:5.000 scale.

2. Neotectonic mapping at 1:5.000 scale (Fig. 2).

3. Test Drillings (Fig. 3).

4. Geotechnical mapping at 1:5.000 scale.

5. Geotechnical survey and sampling in 22 locations - Geotechnical rock mass classification in 22 locations (according to Bieniawski). 


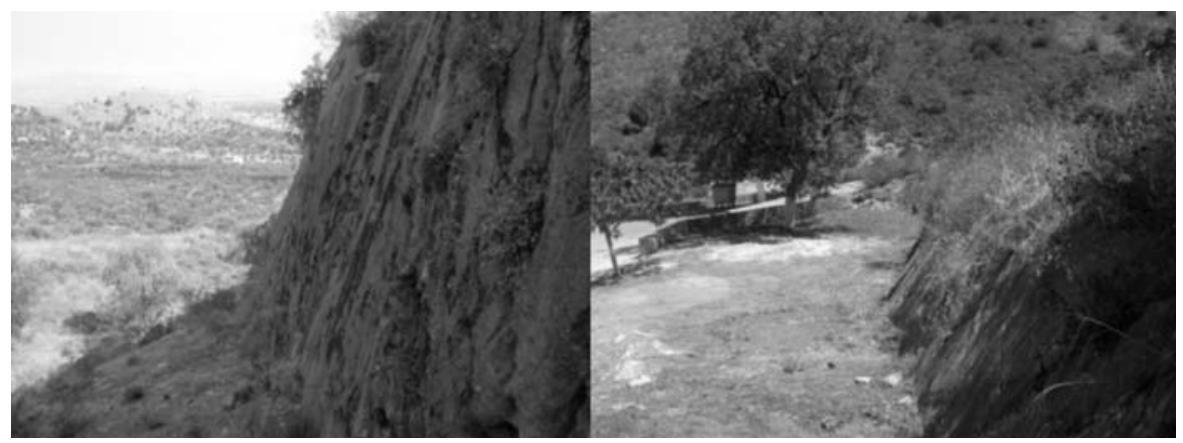

Fig. 2: Neotectonic faults occurring at the broader area of Nafplio (Galanakis and Georgiou, 2008).

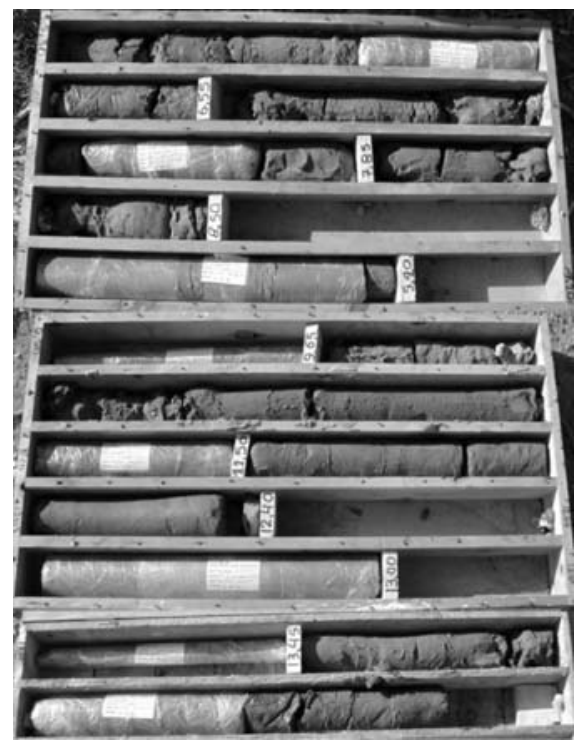

Fig. 3: Test drilling core samples taken from the broader area of Nafplio (Pantelias, 2009).

6. Hydrogeological survey, piezometric measurements, water sampling in 5 locations and chemical analyses (Ca, $\left.\mathrm{C}^{-}, \mathrm{Na}, \mathrm{NH} 4, \mathrm{NO} 2, \mathrm{NO} 3, \mathrm{SO} 4\right)$.

7. Soil sampling in 144 locations and geochemical analyses for the determination of 44 chemical elements such as $\mathrm{Ag}, \mathrm{As}, \mathrm{B}, \mathrm{Cr}, \mathrm{Cu}, \mathrm{Fe}$, etc.

8. Radon measurements.

9. Marine geological survey (Bathymetry, morphology, sampling) (Fig.4).

10. Geophysical survey (Fig. 5):
a. Cross - hole Seismic measurements.
b. Diffraction seismic measurements.
c. Topographic - gravity measurements.
d, Electromagnetical measurements.
e. Electrical tomography. 

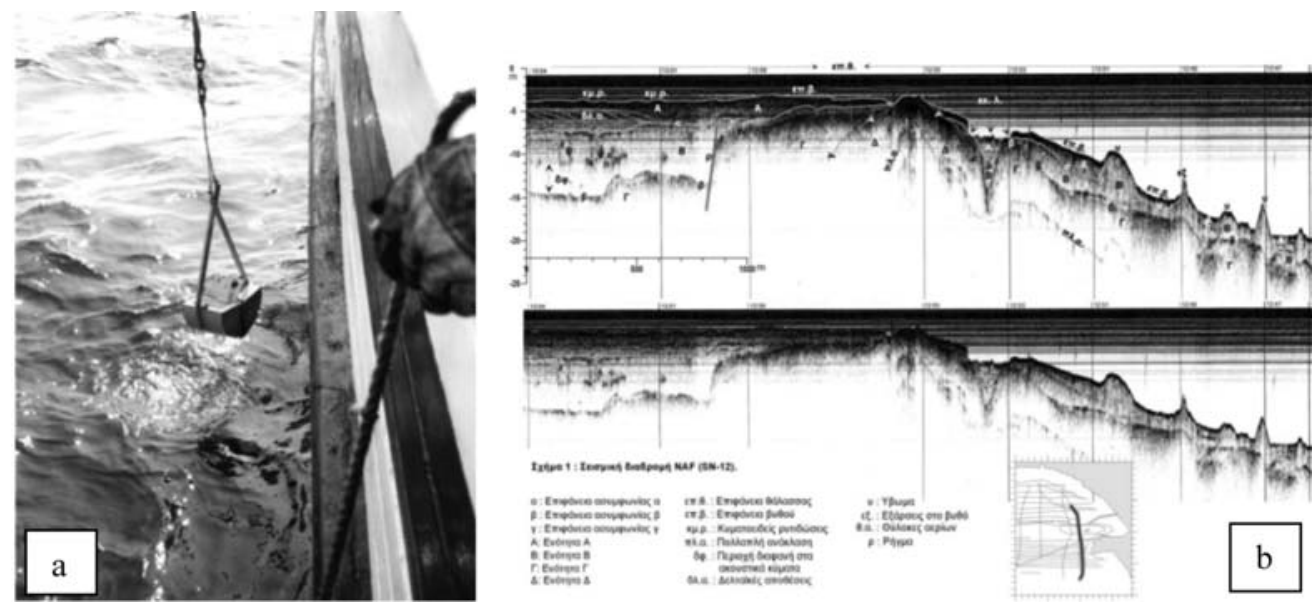

Fig. 4: a) Surface sediment sample collected from the sea floor in the marine area near the city of Nafplio, b) Seismic profile taken from the broader marine area near the city of Nafplio (Andrinopoulos et al., 2008).

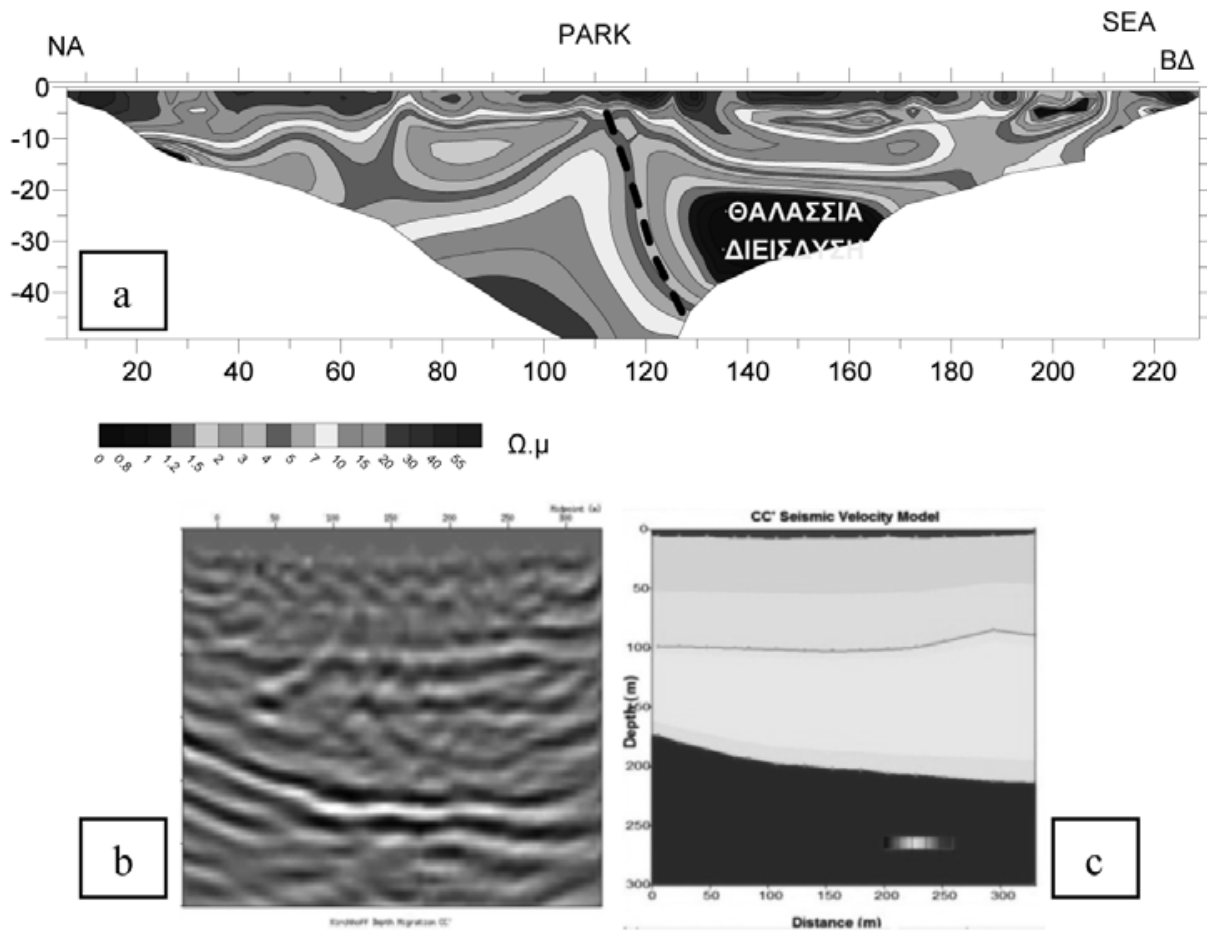

Fig. 5: a) Electric Resistivity Tomography inversion, b) and c) Seismic survey for the detection of possible faults (Karmis, 2008). 

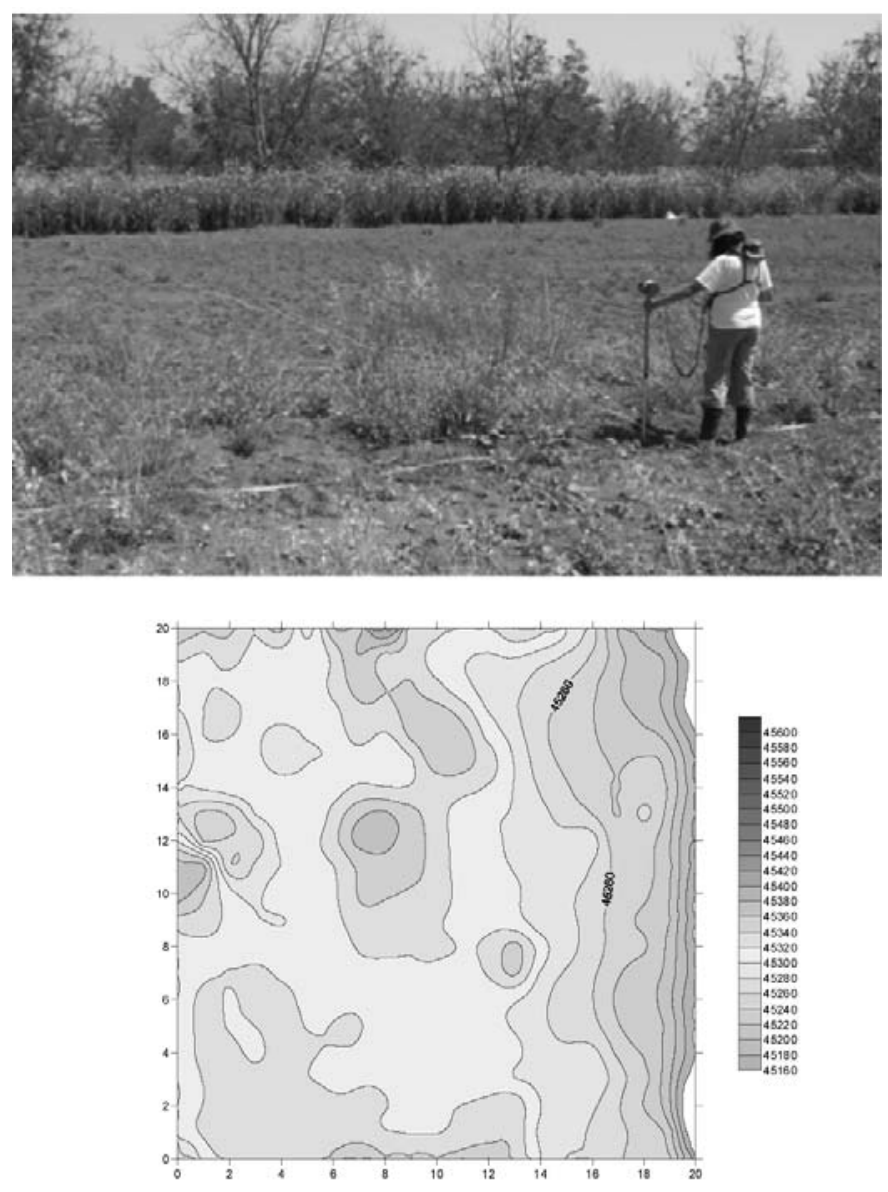

Fig. 6: Magnetic survey near the ancient Agora at the city of Argos (Zananiri, 2009; Zananiri et al., 2010).

11. Geoarchaelogical survey at the broader area of Nafplio (Fig. 6).

12. Geodatabase design, creation and data input.

13. Data management, data analysis.

14. Thematic maps compilation.

15. DEMs and other digital 2D and 3D surfaces creation.

\subsection{Urban Geology Geodatabase}

The complexity of Urban Geology geoinformation can be well stored, described and processed within the frame of a Geographic Information System (GIS).

All geoscientific information derived from field work and data elaboration was stored and processed into a geographic database specially designed for such data. For this specific application an ArcGIS Personal Geodatabase was created (Fig.7). 

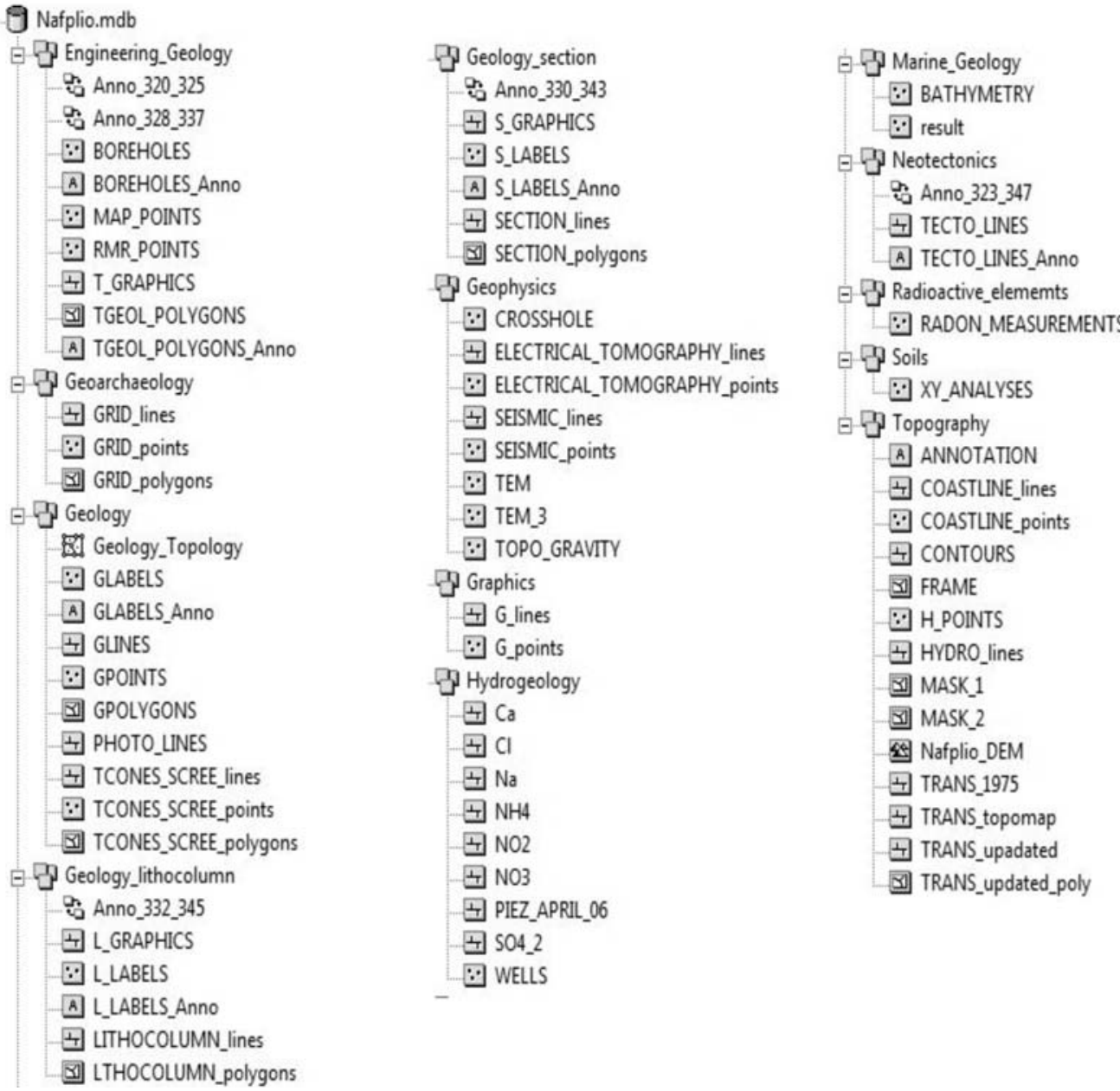

Fig. 7: "Nafplio" Geodatabase structure and content (Zervakou and Tsombos, 2010).

\subsection{Thematic maps and other digital products}

Maps are the best tool to represent, describe, interpret and understand the real world. A map provides information on the existence, the location, the distance and the relation between spatial features. Therefore, any spatial planning, like urban planning, requires a supply of maps.

All processed fieldwork data and results derived from this particular project are presented in geothematic maps and 2D - 3D digital models - surfaces. Two samples of the produced geothematic digital products are displayed bellow (Fig. 8 \& 9).

\section{Conclusions}

Natural hazards are geological and environmental phenomena occurring at irregular intervals and at varying intensity. Urban areas are more at risk than others, depending on natural factors such as ge- 


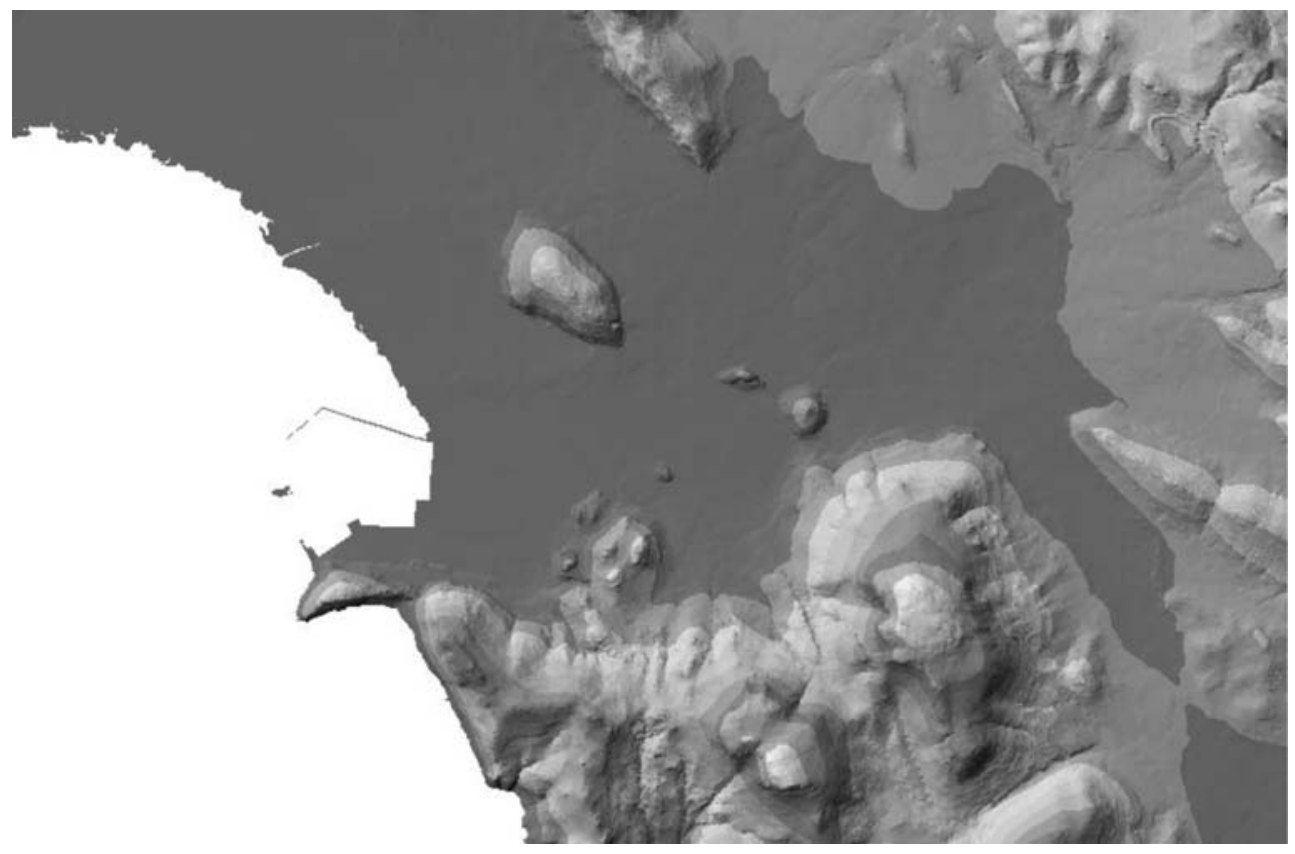

Fig. 8: High detailed TIN representing the surface morphology of the study area (Zervakou et al., 2007).
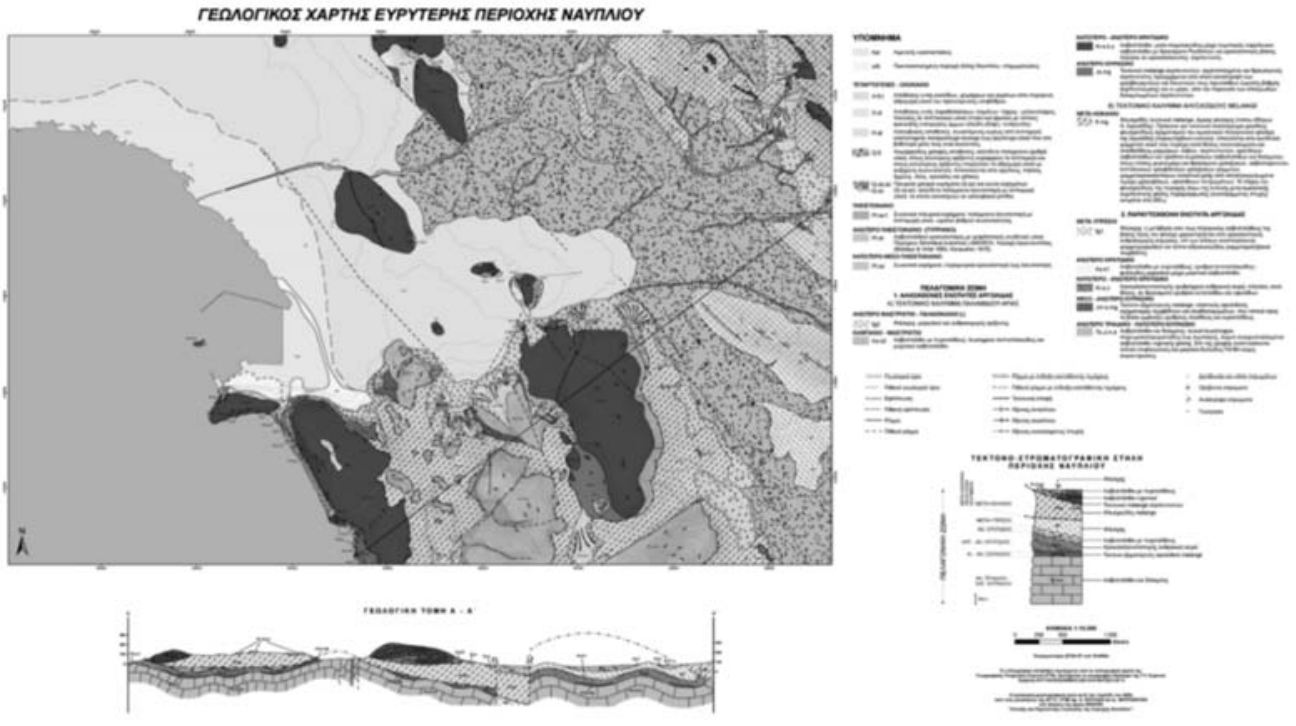

Fig. 9: Geological map of the study area (Photiades, 2008). 
ology, topography and intensive human activities. Today, scientific knowledge and advanced technologies are applied for hazard evaluation and risk reduction, sustainable land use and urban planning.

Urban Geology is working towards inducing decision makers and planers to take into account all geological factors in order to predict and minimize natural hazard, protect and harmonize natural environment in urbanized areas.

Urban Geology project of I.G.M.E., accomplished within the framework of CSF 2000 - 2006, focused on the collection and management of geothematic information concerning urban and suburban areas. Specialized and dedicated studies took place at four pilot urban areas. Nafplio, the capital city of Argolis prefecture, was one of them.

Geographic Information Systems provided the best environment for the collection, storage, management, processing, analysis and cartographic representation of complex geoscientific information. All compiled data were stored, processed in geodatabase and presented in a set of thematic maps and other 2D and 3D digital products.

Geological information constitutes the essential knowledge base for a country development. Thus, the concentration of a big volume of data (maps, technical reports, laboratory analyses etc) in the Institute of Geology and Mineral Exploration will facilitate the geoinformation dissemination to public sector, companies and individuals.

To conclude, through this pilot project new scientific approaches, methodologies and standards were developed and improved in order to apply to other future projects concerning capital centers of the whole country.

\section{Acknowledgements}

This study was accomplished within the framework of the project "Collection and Documentation of Geothematic Information for Urban and Suburban areas in Greece - Pilot Applications". The program was funded by the Operational Program "Competitiveness" Priority Axis 7: Energy and Sustainable Development, Measure 7.3: Exploitation of natural resources and support in meeting environmental commitments. The Operational Program "Competitiveness" was co-funded by the European Regional Development Fund (ERDF).

We would like to thank all colleagues who participated in this multidisciplinary project: Andrinipoulos A., Apostolidis E., Chiotis E., Chiras S., Demetriades A., Efthimiou G., Filos G., Galanakis D., Ganotis G., Georgiou Ch., Iordanidis S., Karageorgiou D., Karmis P., Karpetas Th., Kokkalis Th., Kostopoulos A., Koukis G., Koukoulis A., Kousoulas F., Koutsouveli A., Kyriakopoulos Th., Lappas I., Letsios K., Loupasakis C., Manazis St., Mastrogiannis F., Michalopoulos N., Mitropoulos D., Moraiti E., Nikolaides M., Nikolakopoulos K., Nikolaou N., Panagopoulos A., Pantelias E., Paraschakis Th., Photiades A., Pisinas K., Polyzou L., Sampatakakis P., Spyropoulos I., Tassiou S., Tsiounis E., Tzoumas S., Vassiliades E., Vertsiotis V., Zacharaki P., Zagouroglou C., Zananiri I. and Zimianitis E. Special acknowledgment is granted to the team of the Geodynamics Institute of the National Observatory of Athens (scientific responsible: Karastathis V.) and the geologists Hademenos V., Maroulakis Sp. for their systematic work and support.

\section{References}

Andrinopoulos, A., Zacharaki, E., Zimianitis, E., Maroulakis, S., Mitropoulos, D. and Efthimiou, G., 
2008. Marine geological study of the Northern Argolic gulf. Technical report, IGME, Athens, Greece.

Galanakis, D. and Georgiou, Ch., 2008. Neotectonic study of the urban and suburban area of Nafplio (pilot application). Technical report, IGME, Athens, Greece.

Giroux, D., Bélanger, J.R., 2003. An interactive map viewer for the Urban Geology of Ottawa (Canada): an example of web publishing. European Geophysical Society, Geophysical Research Abstracts, Vol. 5, 00842. Available online at: http://www.cosis.net/abstracts /EAE03/00842/ EAE03-J-00842.pdf

Karmis, P., 2008. Electrical - electromagnetical survey at the urban area of Nafplio, Argolis prefecture. Technical report, IGME, Athens, Greece.

Legget, R.F., 1969. Urban Geology. Canadian Building Digest, CBD - 113, National Research Council Canada. Available online at: http://irc.web-t.cisti.nrc.ca/cbd/cbd113e.html

Pantelias, E., Zervakou, A., Tsombos, P. and Nikolakopoulos, K., 2008. Spatial database for the management of Urban Geology geothematic information: the case of Drama City, Greece. Proceedings, $15^{\text {th }}$ International Symposium on Remote Sensing of the International Society for Optical Engineering, September 15-19, Cardiff, Wales, United Kingdom, Proc. SPIE, Vol. 7110.

Pantelias, E., 2009. Test drillings at the urban and suburban pilot area of Nafplio, Argolis prefecture. Technical report, IGME, Athens, Greece.

Photiades, A., 2008. Geological study of the urban and suburban pilot area of Nafplio, Argolis prefecture. Technical report, IGME, Athens, Greece.

Rau, J., 2005. Teaching Urban Geology from the Bottom Up. Geotimes. Available online at: http://www.agiweb.org/geotimes/oct05/comment.html

Zananiri, I., 2009. Geomagnetic survey at the city of Argos, Argolis Prefecture. Technical report, IGME, Athens, Greece.

Zananiri, I., Hademenos, V. and Piteros, Ch., 2010. Geophysical investigations near the ancient Agora at the city of Argos, Greece. Journal of Geophysics and Engineering, Vol. 7.

Zervakou, A., Tsombos, P. and Nikolakopoulos, K., 2007. Urban Geology: Documentation of geo-thematic information for urban areas in Greece: the case of Nafplion. Proceedings, $14^{\text {th }}$ International Symposium on Remote Sensing of the International Society for Optical Engineering, September17-20 , Palazzo degli Affari Conference Ctr., Florence, Italy, Proc. SPIE, Vol. 6749 p. 67491G1-12.

Zervakou, A., Tsombos, P. and Nikolakopoulos, K., 2008. Urban Geology and GIS: The example of IGME. $5^{\text {th }}$ Greek Conference HellasGIs: "GIS and Environment», December 4-5, Athens, Greece.

Zervakou, A.D. and Tsombos, P.I., 2010. GIS in Urban Geology: the case study of Nafplio, Argolis prefecture, Greece. Bulletin of the Geological Society of Greece, Proceedings of the $12^{\text {th }}$ International Congress (this volume). 